Journal of Southeast Asian

\title{
[Special Issue on SEA Demographics] Response - Language Policy: Using the American Community Survey to Investigate Bilingualism and Biliteracy among Immigrant Communities
}

Gerda de Klerk

Arizona State University, gdk@asu.edu

Terrence G. Wiley

Center for Applied Linguistics, twiley@asu.edu

Follow this and additional works at: https://docs.lib.purdue.edu/jsaaea

Part of the Social Policy Commons

\section{Recommended Citation}

de Klerk, Gerda and Wiley, Terrence G. (2008) "[Special Issue on SEA Demographics] Response - Language Policy: Using the American Community Survey to Investigate Bilingualism and Biliteracy among Immigrant Communities," Journal of Southeast Asian American Education and Advancement. Vol. 3 : Iss. 1, Article 16.

DOI: $10.7771 / 2153-8999.1112$

Available at: https://docs.lib.purdue.edu/jsaaea/vol3/iss1/16

This document has been made available through Purdue e-Pubs, a service of the Purdue University Libraries. Please contact epubs@purdue.edu for additional information.

This is an Open Access journal. This means that it uses a funding model that does not charge readers or their institutions for access. Readers may freely read, download, copy, distribute, print, search, or link to the full texts of articles. This journal is covered under the CC BY-NC-ND license. 


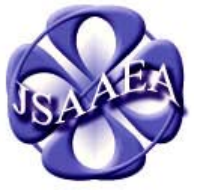

Volume 3

\section{Journal of Southeast Asian American \\ Education \& Advancement}

WwW.JSAAEA.org
A peer-reviewed

scholarly journal

published by the

National Association

for the Education \&

Advancement of

Cambodian, Laotian, and Vietnamese

Americans (NAFEA)

\title{
Special Issue on Southeast Asian American Demographics
}

\section{Response-Language Policy: Using the American Community Survey to Investigate Bilingualism and Biliteracy among Immigrant Communities ${ }^{1}$}

\author{
Gerda de Klerk and Terrence G. Wiley \\ Arizona State University
}

\begin{abstract}
This article is a response to Mark Pfeifer's Cambodian, Hmong, Lao and Vietnamese Americans in the 2005 American Community Survey and elaborates on the utility of the American Community Survey (ACS) for studying immigrant groups in the United States of America, and also compares the ACS to the U.S. Census. Neither the Census nor ACS questionnaire is structured to capture the language and literacy skills of immigrant communities in as far as these surveys only collect information about respondents' oral language abilities, with a focus on English fluency. Direct, self-reported, and surrogate measures of literacy are discussed, with a proposal to use education level as surrogate for literacy. Using the Vietnamese subpopulation in the ACS, examples are presented of ways to construct composite variables from the ACS raw microdata, to measure respondents' bilingualism and biliteracy. When such new variables are used in analysis of immigrant communities, a more complex multilingual picture emerges than is presented normally in Census and ACS data products available to the public.
\end{abstract}

Mark Pfeifer provides a useful analysis of the 2005 American Community Survey by the U.S. Census Bureau. Such datasets are not ideal for informing educational and language policies, but they can help to provide baseline information regarding overall characteristics of immigrant and other minority groups in terms of language, education, and socioeconomic well being. These data are particularly useful when noting trends over time for specific groups or comparing the relative condition and performance of specific groups.

What is not clear is the extent to which educational policy makers consider these data when formulating educational policies that directly affect immigrant language minorities. All too often, major educational policies are formulated as if one-size-fits-all (Wiley \& Wright, 2004).

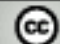

SOMERIGHISRESERVEDReaders are free to copy, display, and distribute this article, as long as the work is attributed to the author(s) and the Journal of Southeast Asian American Education \& Advancement, it is distributed for noncommercial purposes only, and no alteration or transformation is made in the work. More details of this Creative Commons license are available at http://creativecommons.org/licenses/by-nc-nd/3.0/. All other uses must be approved by the author(s) or JSAAEA. 
Thus, it is refreshing to see Pfeifer's use of the American Community Survey and his focus on specific populations such as Vietnamese, Cambodians, Lao, and Hmong. All too often these groups are just subsumed under the labels of “Asian” or "Southeast Asian." In evaluating these data, it is important to note Pfeifer's qualification:

This concise article is intended to provide basic 2005 demographic, educational and socioeconomic data related to Cambodian, Hmong, Lao and Vietnamese in the United States. It is not intended as a comprehensive explanatory research paper of factors underlying contemporary demographic, educational and socioeconomic trends in these four ethnic communities. (p. 1)

This qualification is both modest and important. Pfeifer's and similar contributions are useful and necessary starting points. Pfeifer's approach is to use the interactive features of the ACS website which allow for specific tabulations. Users can pull up summary tables and tabular and narrative profile reports for a particular region or population. His report illustrates that a great deal of useful data can be gleaned from the ACS site without having to manipulate the actual raw micro data set.

We will demonstrate, however, that working directly with the raw data from the ACS can yield interesting information beyond what is possible from the ACS website. In particular, we will illustrate how additional variables can be constructed and cross-tabulated to provide new insights regarding bilingualism, literacy, and biliteracy of language minority populations. First, we will provide a rationale for doing secondary data analyses with U.S. Census and ACS data sets, a brief comparison of the strengths and limitations of each, as well as some background regarding the utility and limitations of these data sets related to language and literacy.

\section{Using the U.S. Census and ACS for Language and Literacy Data}

In much of the public and popular discourse on immigrants and language, there is a tendency to equate literacy with English literacy and, thereby, a failure to acknowledge literacy in languages other than English. This omission tends to inflate perceptions of a literacy "crisis." Millions of people in the United States are literate in languages other than English; they use other languages as resources, but their abilities are often ignored. Analyses of U.S. Census data (Macías, 1988, 1993, 1994, 2000; Macías \& Spencer, 1984) and other nationwide surveys such as the ACS can provide valuable information that can help correct common misperceptions about literacy and language diversity. As Macías (1990) has noted, however, there are three patterns of literacy among U.S. language minority groups: (1) native language literacy, which is literacy in one's mother tongue; (2) second language literacy (typically in English), which implies no literacy in one's native language; and (3) biliteracy, or literacy in two languages (typically in one's native language and in English). Nonliteracy (i.e., no literacy in any language) is also a possibility for those who speak a language that has no written form. The term illiteracy carries the negative connotation that one is not educated (Wiley, 2005; see also Venezky, Wagner, \& Ciliberti, 1990). 


\section{Confusing Oral Proficiency with Literacy}

Limited English speaking proficiency is sometimes confused with illiteracy. In the U.S. Census, the only question dealing with language proficiency is focused on English oral proficiency (“How well does this person speak English?”). Some language minority individuals can read, or read and write in English, but they may not speak the language very well. Then again, some people who are fluent in speaking English may not be English literate. Thus, the challenges of becoming literate in a second language need to be differentiated from the difficulties of learning to speak a second language and from trying to develop initial literacy in a first or second language (Wiley, 2005). Census or ACS surveys can be useful in helping us to gather information about the language and literacy characteristics of the general population or specific language minority groups, but we first have to recognize the limitations of the original surveys and the approaches to gathering data about language and literacy and the strength and limitations of using those data to make claims about the characteristics of the population.

\section{Approaches to Measuring Literacy and Biliteracy}

There are three basic approaches to measuring language and literacy abilities: (1) direct measures or tests, (2) self-reported measures, and (3) surrogate measures, which use a certain number of years of schooling as an indicator of literacy. Direct measures are always preferable to selfreported or surrogate indicators, but they are costly and not without problems of authentically representing peoples' language and literacy abilities. Thus, self-reported abilities in U.S. Census and ACS surveys and surrogate measures constructed from these data have considerable utility in trying to generalize about large segments of the population (See Wiley, 2005 for further discussion of direct measures of literacy/biliteracy; see also Macías, 1988; 1993; 1994; 2000 regarding the utility of these data for analyses of language diversity in the United States).

\section{Self-Reported Measures of Literacy in the U.S. Census}

The U.S. Census has been the major resource for national literacy data since the middle of the nineteenth century. Initially, the Census asked individuals to respond to a question asking whether they could read or write a simple message in English or some other language. A simple “yes" response was taken to mean that they were literate (Kirsch \& Guthrie, 1977-1978). By the Census in 1930, the self-reported literacy rate was 97 percent for U.S. born whites, 90 percent for foreign born and 84 percent for Blacks (Venezky, Kaestle, \& Sum, 1987). Over time, as most people became literate, the focus shifted to how well people could read and write.

There has been an inclination to mistrust self-reported literacy information because people tend to inflate their abilities (see Schaffner, 2005) and because the questions asked require the respondent to make rather general claims without indicating a context. However, for those who speak "nonstandard" non-prestige varieties of English, or who have learned English as a second language, there may also be an inclination to indicate that they do not use the language very well-regardless of how much English features in their daily lives. Wiley (1988) found that a substantial portion of the Mexican-origin population surveyed in the National Chicano Survey reported that they could not speak any language very well or well. This response, however, correlated with lower levels of schooling. Some evidence indicates that self-assessment is reliable if appropriate controls are employed (LeBlanc \& Painchaud, 1986), and self-reported 
Census data regarding English proficiency have been correlated with direct-measure data from the English Language Proficiency Survey (ELPS), with a strong relationship being found between the two (McArthur, 1993).

\section{Years of Schooling as a Surrogate Measure of Literacy}

Literacy can also be inferred from years of schooling. Grade-level surrogates have been used for convenience of having an easily available surrogate indicator. In 1940, the U.S. Army, for example, equated completion of the fourth grade as the equivalent of literacy, raised to completion of the fifth grade in 1947, and in 1952 finally settled on sixth grade (Hunter \& Harman, 1979). Some have contended that an eighth- or even twelfth-grade equivalence is preferable (Venezky, Kaestle, \& Sum, 1987). Still others conclude that years of schooling is not a reliable measure of literacy skills (Hunter \& Harman, 1979; Kirsch \& Guthrie, 1977/1978). International agencies like the World Bank and UNESCO use completion of a full course of primary schooling as a surrogate measure, which could be five or six years of schooling, depending on the country (Schaffner, 2005; The World Bank Group, 2004). The chief weakness of the grade-level completion is that the number of years of schooling one has completed provides no assurance of skills mastered or the quality of schooling received. Nevertheless, years of schooling as an indicator of literacy does allow for cross-group comparisons and allows inferences to be made about literacy in languages other than English even though the Census itself has no specific question related to literacy in other languages.

\section{Comparing the U.S. Census and the ACS}

The American Community Survey (ACS) is a project of the U.S. Census Bureau and replaces the long form in the decennial census. It is an ongoing survey of a sample of three million households each year, and it provides more current information than the Census long form. It fills gaps in the ten year time spans between censuses in order to measure change more accurately. Data products are updated every year. Data for 2007 will be released in August 2008, since data products are released within eight months of data collection, as opposed to two years for the decennial census. The data can be accessed on the American Factfinder interface of the U.S. Census Bureau website as data tables, data briefs, ranking tables, and fact sheets; and the Public Use Microdata Sample File (PUMS) can be downloaded from the same website. Table 1 provides a brief comparison of the U.S. Census and ACS.

Because the ACS replaces the long form of the U.S. Census, language related questions in the ACS are similar to those that appear in the decennial census. At the individual level information is gathered about spoken ability in English, about whether a person speaks a language other than English at home, and if so, what this language is. As noted earlier, these questions do not elicit a person's literacy levels, or any knowledge or usage of a language other than English except for oral use in the home. At the household level, the ACS assesses whether a household is "linguistically isolated," which means that no person 14 or over in the household speaks English "very well.” 
Table 1

Comparison of Decennial Census and American Community Survey

\begin{tabular}{|c|c|c|}
\hline Characteristics & Decennial Census & American Community Survey \\
\hline Method & 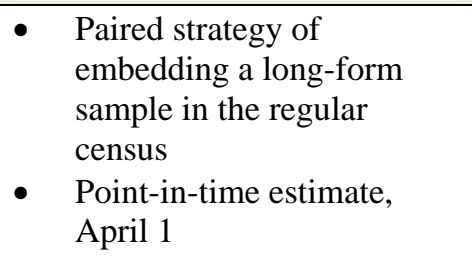 & $\begin{array}{ll} & \text { Long form sample } \\
\text { - } & \text { Period estimate }\end{array}$ \\
\hline Numbers & $\begin{array}{l}\text { - Complete U.S. population } \\
\text { count }\end{array}$ & - 3 million per year \\
\hline Frequency & - $\quad$ Once every ten years & $\begin{array}{l}\text { - } \quad \text { Mailed each month to 250,000 people } \\
\text { - Conducted on continuous basis with } \\
\text { data released each year }\end{array}$ \\
\hline Unit of analysis & $\begin{array}{l}\text { - } \quad \text { Short form: block } \\
\text { - Long form: tracts and block } \\
\text { groups (Could not go down } \\
\text { to a block because of } \\
\text { estimates not being precise } \\
\text { enough at that level and } \\
\text { because of confidentiality } \\
\text { issues). }\end{array}$ & $\begin{array}{l}\text { - In } 2006 \text { and } 2007 \text { data released for } \\
\text { previous calendar year (1 year) for } \\
\text { areas with 65,000 people or more. } \\
\text { In } 2008 \text { data spanning 2005-2007 (3 } \\
\text { years) will be released for areas with } \\
\text { 20, } 000 \text { people or more } \\
\text { In } 2008 \text { data spanning } 2005-2009 \text { (5 } \\
\text { years) will be released for all areas } \\
\text { down to groups of blocks. } \\
\text { Each year the 1, 3, and } 5 \text { year estimates } \\
\text { will be updated to reflect newer data }\end{array}$ \\
\hline Accuracy and Quality & $\begin{array}{l}\text { For short form, less } \\
\text { detailed information, but no } \\
\text { sampling issues to } \\
\text { consider, except related to } \\
\text { people who do not return } \\
\text { their forms. } \\
\text { Long form has traditionally } \\
\text { high rates of non- } \\
\text { completion and non-return } \\
\text { Unsystematic and } \\
\text { unpredictable error } \\
\text { introduced when making } \\
\text { projections from ten year } \\
\text { interval data. Better } \\
\text { projections possible with } \\
\text { ACS. (MacDonald, 2006) }\end{array}$ & $\begin{array}{l}\text { - More detailed information in the long } \\
\text { form. Estimation issues are a problem, } \\
\text { there are larger margins of error in } \\
\text { ACS estimates, and weights need to be } \\
\text { used. } \\
\text { Better follow up with ACS than with } \\
\text { Census long form, so higher } \\
\text { completion and return rates. } \\
\text { Sampling estimated to be } 1.33 \text { times } \\
\text { that of the long form (MacDonald, } \\
\text { 2006) }\end{array}$ \\
\hline
\end{tabular}

\section{Constructing Variables for Bilingualism, Literacy, and Biliteracy}

Given that the primary focus of language surveying in the U.S. Census and ACS is on English oral proficiency, it is necessary to construct variables for secondary data analysis related to literacy, biliteracy, and bilingualism, based on, and qualified by some operational assumptions. We will now show briefly how we used the ACS raw data pertaining to one of the groups in 
Pfeifer's discussion-Vietnamese - to examine patterns between existing variables in the data set, as well as patterns between existing variables and composite variables we created. We were ultimately interested in finding a way to measure native language literacy and thus needed to select from the larger dataset those who most likely had spent their primary school years in a Vietnamese environment.

Our first step was to select from the $2006^{2}$ PUMS all respondents who identified their race as "Vietnamese." Second, from this subset, we selected respondents who were born outside of the United States, Vietnam specifically, and did not enter the United States before 12 years of age. What we were trying to delineate was those respondents who would have been eligible for primary education in Vietnam. ${ }^{3}$ The primary education system in Vietnam has traditionally encompassed grades one to five (no kindergarten), with children entering at age six (turning seven during first grade) (UNESCO Asia and Pacific Regional Bureau for Education, 2007). We selected from the "Vietnamese" subset all of those born in Vietnam, who were 12 years or older when entering the United States of America for the first time as immigrants or refugees.

The assumption here is that if these people had had age appropriate education in their home country, by age 12 they could have been at the equivalent of seventh grade, but would at least have been at the equivalent of fifth grade, that is, they would have completed primary school and would be literate in Vietnamese. We assume that many of these immigrants may have had interrupted education because of conflict in their home country and the time it took them to immigrate to the United States of America, and that using anything less than 12 years as cut off age to capture respondents who were old enough to have completed primary school age may be a misrepresentation of peoples' actual experience.

Third, we then recoded the 16 categories in the ACS for educational level attained by collapsing them to nine categories, which would yield more meaningful cross tabulations than an unwieldy large set of categories.

An examination of English fluency for this subset of respondents showed that 19.2\% spoke English very well, 35.5\% spoke it well, 36\% spoke it not well, and $9.3 \%$ did not speak English at all (see Table 2.) We were interested in establishing the relationship between education level, and oral English proficiency. A comparison of the English spoken ability responses (directly from the survey) with education levels (from the survey, but recoded to fewer categories) is presented in Table 2. A positive correlation of English fluency with higher education levels was expected. Not surprisingly then there is a clear trend showing that among those who speak English very well, or well, we find larger proportions of people at the higher education level end of the spectrum, while among those who do not speak English at all, larger proportions of respondents have lower education levels. When looking at the education levels of the respondents, the largest cluster is among those with a high school degree or less than one year of college (27.1\%). Whether this clustering is related to a specific age distribution with big proportions of youth, or for some other reason, can be further explored if desired using this dataset.

The next step was to manipulate variables to create new measures not available directly in the dataset. We were interested in gauging the extent of oral bilingual language ability (not just English ability) of an individual, based on self reporting of language fluencies, and cross tabulate this with education level. A bilingual variable was constructed by matching responses to the question about English ability with the question about whether the person spoke a language other than English at home. This construction yielded five categories on a spectrum: (1) first language (L1) monolinguals; (2) bilinguals who speak a language other than English at home and 
speak English not well; (3) bilinguals who speak a language other than English at home, and speak English well; (4) bilinguals who speak a language other than English at home and speak English very well; and (5) English monolinguals.

Table 2

Relationship Between English Oral Proficiency and Education Level for Individuals Born in Vietnam who Arrived in the U.S. at Age 12 or Older.

\begin{tabular}{|c|c|c|c|c|c|}
\hline \multicolumn{6}{|c|}{ How Well Does This Person Speak English? } \\
\hline Education level & Very well & Well & Not well & Not at all & Total \\
\hline $\begin{array}{l}\text { No school completed } \\
\% \text { of Total }\end{array}$ & $\begin{array}{r}1.8 \% \\
(.4)\end{array}$ & $\begin{aligned} 1.6 \% \\
(.6)\end{aligned}$ & $\begin{array}{r}7.8 \% \\
(2.8)\end{array}$ & $\begin{array}{r}24.3 \% \\
(2.2)\end{array}$ & $6.0 \%$ \\
\hline $\begin{array}{l}\text { Nursery school to grade } 4 \\
\% \text { of Total }\end{array}$ & $\begin{array}{l}.6 \% \\
(.1)\end{array}$ & $\begin{array}{l}.3 \% \\
(.1)\end{array}$ & $\begin{array}{r}2.9 \% \\
(1.0)\end{array}$ & $\begin{array}{r}9.0 \% \\
(.8)\end{array}$ & $2.1 \%$ \\
\hline $\begin{array}{l}\text { Grade } 5,6,7,8 \\
\text { \% of Total }\end{array}$ & $\begin{array}{r}1.8 \% \\
(.4)\end{array}$ & $\begin{array}{r}3.3 \% \\
(1.2)\end{array}$ & $\begin{array}{r}12.6 \% \\
(4.5)\end{array}$ & $\begin{array}{r}21.4 \% \\
(2.0)\end{array}$ & $8.0 \%$ \\
\hline $\begin{array}{l}\text { Grade } 9 \text { and } 10 \\
\% \text { of Total }\end{array}$ & $\begin{array}{r}2.7 \% \\
(.5)\end{array}$ & $\begin{array}{r}4.6 \% \\
(1.6)\end{array}$ & $\begin{array}{r}10.5 \% \\
(3.8)\end{array}$ & $\begin{array}{r}10.1 \% \\
(.9)\end{array}$ & $6.9 \%$ \\
\hline $\begin{array}{l}\text { Grade } 11 \text { and incomplete Grade } 12 \\
\% \text { of Total }\end{array}$ & $\begin{array}{r}3.8 \% \\
(.7)\end{array}$ & $\begin{array}{r}10.3 \% \\
(3.6)\end{array}$ & $\begin{array}{r}15.4 \% \\
(5.5)\end{array}$ & $\begin{array}{r}9.3 \% \\
(.9)\end{array}$ & $10.8 \%$ \\
\hline $\begin{array}{l}\text { High school grad or college }<1 \mathrm{yr} \\
\% \text { of Total }\end{array}$ & $\begin{array}{r}18.3 \% \\
(3.5)\end{array}$ & $\begin{array}{r}28.1 \% \\
(10.0)\end{array}$ & $\begin{array}{r}33.0 \% \\
(11.9)\end{array}$ & $\begin{array}{r}18.9 \% \\
(1.8)\end{array}$ & $27.1 \%$ \\
\hline $\begin{array}{l}\text { Some college or Associate's degree } \\
\% \text { of Total }\end{array}$ & $\begin{array}{r}23.3 \% \\
(4.5)\end{array}$ & $\begin{array}{r}27.7 \% \\
(9.8)\end{array}$ & $\begin{array}{r}12.1 \% \\
(4.4)\end{array}$ & $\begin{array}{r}3.2 \% \\
(.3)\end{array}$ & $19.0 \%$ \\
\hline $\begin{array}{l}\text { Bachelor's degree } \\
\% \text { of Total }\end{array}$ & $\begin{array}{r}31.7 \% \\
(6.1)\end{array}$ & $\begin{array}{r}19.4 \% \\
(6.9)\end{array}$ & $\begin{array}{r}4.9 \% \\
(1.8)\end{array}$ & $\begin{array}{r}2.5 \% \\
(.2)\end{array}$ & $15.0 \%$ \\
\hline $\begin{array}{l}\text { Graduate or Professional degree } \\
\% \text { of Total }\end{array}$ & $\begin{array}{r}15.8 \% \\
(3.0)\end{array}$ & $\begin{array}{r}4.7 \% \\
(1.7)\end{array}$ & $\begin{aligned} .9 \% \\
(.3)\end{aligned}$ & $\begin{array}{r}1.3 \% \\
(.1)\end{array}$ & $5.2 \%$ \\
\hline $\begin{array}{l}\text { Total } \\
\% \text { of Total }\end{array}$ & $\begin{array}{r}100.0 \% \\
(19.2)\end{array}$ & $\begin{array}{r}100.0 \% \\
(35.5)\end{array}$ & $\begin{array}{r}100.0 \% \\
(36.0)\end{array}$ & $\begin{array}{r}100.0 \% \\
(9.3)\end{array}$ & $100.0 \%$ \\
\hline
\end{tabular}

Once respondents' oral language abilities in languages other than English are taken into consideration, a slightly more complex picture emerges (see Table 3). What we see now is not only that oral English is positively associated with higher levels of education, but so is oral bilingualism. Those who are bilingual in English and another language, have a larger representation in higher education level categories. The fact that among English monolinguals we find higher representation in the higher education level categories than in the lower education categories (and among L1 monolinguals the opposite), is strong evidence that English is always associated with higher levels of education. However, in only using the existing variables in a survey like the ACS, it may be easy to misinterpret findings as in Table 2 above as showing a zero sum relationship between L1 and second language (L2) fluency and educational achievement. Creating composite variables make visible characteristics of the educated immigrant population that are not discernible by using only what is available in the dataset.

As mentioned earlier, Census surveys do not measure literacy levels, so we have proceeded to use schooling as a surrogate measure of literacy for this analysis. We were particularly interested in literacy in the first language, and thus constructed a literacy variable 
that would account for schooling in the first language, in this case Vietnamese. Several assumptions underlie the construction of the literacy variable.

Table 3

Relationship Between Bilingual Oral Ability and Education Level for Individuals Born in Vietnam who Arrived in the U.S. at Age 12 or Older.

\begin{tabular}{|c|c|c|c|c|c|c|}
\hline \multirow[b]{2}{*}{ Education level } & \multicolumn{5}{|c|}{ Oral Bilingual Ability } & \multirow[b]{2}{*}{ Total } \\
\hline & $\begin{array}{c}\text { Bilingual- } \\
\text { English } \\
\text { Very } \\
\text { Well }\end{array}$ & $\begin{array}{l}\text { Bilingual- } \\
\text { English } \\
\text { Well }\end{array}$ & $\begin{array}{l}\text { Bilingual- } \\
\text { English Not } \\
\text { Well }\end{array}$ & $\begin{array}{l}\text { L1 mono- } \\
\text { lingual }\end{array}$ & $\begin{array}{l}\text { English } \\
\text { mono- } \\
\text { lingual }\end{array}$ & \\
\hline $\begin{array}{l}\text { No school completed } \\
\% \text { of Total }\end{array}$ & $\begin{array}{r}1.8 \% \\
(.3)\end{array}$ & $\begin{array}{r}1.6 \% \\
(.6)\end{array}$ & $\begin{array}{l}7.8 \% \\
(2.7)\end{array}$ & $\begin{array}{r}24.3 \% \\
(2.2)\end{array}$ & $\begin{array}{r}9.3 \% \\
(.3)\end{array}$ & $6.1 \%$ \\
\hline $\begin{array}{l}\text { Nursery school to grade } 4 \\
\text { \% of Total }\end{array}$ & $\begin{array}{l}.6 \% \\
(.1)\end{array}$ & $\begin{array}{l}.3 \% \\
(.1)\end{array}$ & $\begin{array}{r}2.9 \% \\
(1.0)\end{array}$ & $\begin{array}{r}9.0 \% \\
(.8)\end{array}$ & $\begin{array}{r}4.6 \% \\
(.1)\end{array}$ & $2.1 \%$ \\
\hline $\begin{array}{l}\text { Grade } 5,6,7,8 \\
\% \text { of Total }\end{array}$ & $\begin{array}{r}1.8 \% \\
(.3)\end{array}$ & $\begin{array}{r}3.3 \% \\
(1.1)\end{array}$ & $\begin{array}{r}12.6 \% \\
(4.4)\end{array}$ & $\begin{array}{r}21.4 \% \\
(1.9)\end{array}$ & $\begin{array}{r}5.2 \% \\
(.1)\end{array}$ & $8.0 \%$ \\
\hline $\begin{array}{l}\text { Grade } 9 \text { and } 10 \\
\% \text { of Total }\end{array}$ & $\begin{array}{r}2.7 \% \\
(.5)\end{array}$ & $\begin{array}{r}4.6 \% \\
(1.6)\end{array}$ & $\begin{array}{r}10.5 \% \\
(3.7)\end{array}$ & $\begin{array}{r}10.1 \% \\
(.9)\end{array}$ & $\begin{array}{r}4.6 \% \\
(.1)\end{array}$ & $6.8 \%$ \\
\hline $\begin{array}{l}\text { Grade } 11 \text { \& incomplete Grade } 12 \\
\% \text { of Total }\end{array}$ & $\begin{array}{r}3.8 \% \\
(.7)\end{array}$ & $\begin{array}{r}10.3 \% \\
(3.5)\end{array}$ & $\begin{array}{r}15.4 \% \\
(5.4)\end{array}$ & $\begin{array}{r}9.3 \% \\
(.8)\end{array}$ & $\begin{array}{r}6.7 \% \\
(.2)\end{array}$ & $10.6 \%$ \\
\hline $\begin{array}{l}\text { High school grad or college }<1 \text { year } \\
\% \text { of Total }\end{array}$ & $\begin{array}{r}18.3 \% \\
(3.4)\end{array}$ & $\begin{array}{r}28.1 \% \\
(9.7)\end{array}$ & $\begin{array}{r}33.0 \% \\
(11.5)\end{array}$ & $\begin{array}{r}18.9 \% \\
(1.7)\end{array}$ & $\begin{array}{r}27.3 \% \\
(.8)\end{array}$ & $27.1 \%$ \\
\hline $\begin{array}{l}\text { Some college or Associate's degree } \\
\% \text { of Total }\end{array}$ & $\begin{array}{r}23.3 \% \\
(4.4)\end{array}$ & $\begin{array}{r}27.7 \% \\
(9.5)\end{array}$ & $\begin{array}{r}12.1 \% \\
(4.2)\end{array}$ & $\begin{array}{r}3.2 \% \\
(.3)\end{array}$ & $\begin{array}{r}16.0 \% \\
(.5)\end{array}$ & $18.9 \%$ \\
\hline $\begin{array}{l}\text { Bachelor's degree } \\
\% \text { of Total }\end{array}$ & $\begin{array}{r}31.7 \% \\
(5.9)\end{array}$ & $\begin{array}{r}19.4 \% \\
(6.7)\end{array}$ & $\begin{array}{r}4.9 \% \\
(1.7)\end{array}$ & $\begin{array}{r}2.5 \% \\
(.2)\end{array}$ & $\begin{array}{r}21.6 \% \\
(.6)\end{array}$ & $15.2 \%$ \\
\hline $\begin{array}{l}\text { Graduate or Professional degree } \\
\% \text { of Total }\end{array}$ & $\begin{array}{r}15.8 \% \\
(3.0)\end{array}$ & $\begin{array}{r}4.7 \% \\
(1.6)\end{array}$ & $\begin{array}{l}.9 \% \\
(.3)\end{array}$ & $\begin{array}{r}1.3 \% \\
(.1)\end{array}$ & $\begin{array}{r}9.3 \% \\
(.3)\end{array}$ & $5.3 \%$ \\
\hline $\begin{array}{l}\text { Total } \\
\% \text { of Total }\end{array}$ & $\begin{array}{r}100.0 \% \\
(18.7)\end{array}$ & $\begin{array}{r}100.0 \% \\
(34.5)\end{array}$ & $\begin{array}{r}100.0 \% \\
(35.0)\end{array}$ & $\begin{array}{r}100.0 \% \\
(9.0) \\
\end{array}$ & $\begin{array}{r}100.0 \% \\
(2.9)\end{array}$ & $100.0 \%$ \\
\hline
\end{tabular}

From the subpopulation of people who were 12 years or older when they arrived in the United States we consider those who have "No school completed" and "Nursery school to fourth grade” as being "Not literate” in any language, since a fourth grade education does not meet a minimum threshold for literacy. Completion of fifth grade would signal completion of primary school and an acceptable surrogate for literacy. All respondents with five or more years of education were classified as "Literate" in L1 and also possibly English. Those with no more than five years of education may only be literate in Vietnamese; those with six or more years of education would have had their primary schooling in Vietnam, and may have had subsequent schooling in either Vietnam or the United States of America. This means that some of these people will be biliterate in Vietnamese and English, and others may be literate in Vietnamese with no or little English literacy. Even the small percentage of the sample (4.1\%) that only had the equivalent of primary school education, ${ }^{4}$ may have acquired English literacy in non-formal educational contexts later in the United States.

Table 4 illustrates how we compared our new variables that would take into account not only English spoken ability, but bilingual spoken abilities as well as varying degrees of 
biliteracy. Among bilinguals we find very high proportions (ranging from $89.3 \%$ to $98 \%$ ) of literacy, which would include at least literacy in Vietnamese, but for the bulk of respondents literacy in Vietnamese and English. Among L1 monolinguals 66.8\% are literate in Vietnamese. This fact points toward a shortcoming of the language questions in the U.S. Census, that is, using only the existing Census variables, what gets foregrounded for this group is their lack of English oral proficiency, and their oral use of L1 at home. What is invisible is that two-thirds of this group (and 6\% of all respondents) have literacy skills. Among ostensibly English monolinguals, 90.7\% must be literate in their L1, unless their primary schooling was in English, which is highly unlikely given the selection of the subset of respondents. This group-incorrectly identified as monolinguals-makes up $2.6 \%$ of the total sample. In analyzing ACS data, it was only once we attempted to account for language use other than current oral use, and current use at home, that a picture of more complex multilingual abilities emerged.

Table 4

Relationship Between Bilingual Oral Ability and Literacy Skills for Individuals Born in Vietnam who Arrived in the U.S. at Age 12 or Older.

\begin{tabular}{|c|c|c|c|c|c|c|}
\hline \multirow[b]{2}{*}{ Literacy Skills } & \multicolumn{5}{|c|}{ Oral Bilingual Ability } & \multirow[b]{2}{*}{ Total } \\
\hline & $\begin{array}{c}\text { Bilingual- } \\
\text { English Very } \\
\text { Well }\end{array}$ & $\begin{array}{c}\text { Bilingual- } \\
\text { English Well }\end{array}$ & $\begin{array}{l}\text { Bilingual- } \\
\text { English Not } \\
\text { Well }\end{array}$ & $\begin{array}{l}\text { L1 Mono- } \\
\text { lingual }\end{array}$ & $\begin{array}{c}\text { English } \\
\text { Monolingual }\end{array}$ & \\
\hline $\begin{array}{l}\text { Not Literate } \\
\% \text { of Total }\end{array}$ & $\begin{array}{r}2.5 \% \\
(.5)\end{array}$ & $\begin{array}{r}2.0 \% \\
(.7)\end{array}$ & $\begin{array}{r}10.7 \% \\
\text { (3.7) }\end{array}$ & $\begin{array}{r}33.2 \% \\
(3.0)\end{array}$ & $\begin{array}{r}9.3 \% \\
(.3)\end{array}$ & $8.1 \%$ \\
\hline $\begin{array}{l}\text { Literate in L1 (some lite } \\
\text { L2) } \\
\% \text { of Total }\end{array}$ & $\begin{array}{r}97.5 \% \\
(18.2)\end{array}$ & $\begin{array}{r}98.0 \% \\
(33.8)\end{array}$ & $\begin{array}{r}89.3 \% \\
(31.2)\end{array}$ & $\begin{array}{r}66.8 \% \\
(6.0)\end{array}$ & $\begin{array}{r}90.7 \% \\
(2.6)\end{array}$ & $91.9 \%$ \\
\hline $\begin{array}{l}\text { Total } \\
\% \text { of Total }\end{array}$ & $\begin{array}{r}100.0 \% \\
(18.7)\end{array}$ & $\begin{array}{r}100.0 \% \\
(34.5)\end{array}$ & $\begin{array}{r}100.0 \% \\
(35.0)\end{array}$ & $\begin{array}{r}100.0 \% \\
(9.0)\end{array}$ & $\begin{array}{r}100.0 \% \\
(2.9)\end{array}$ & $100.0 \%$ \\
\hline
\end{tabular}

\section{Conclusion}

In this analysis we did not present findings for Cambodians, Lao, and Hmong, as Pfeifer did. The purpose of this analysis was to use one subgroup, Vietnamese, as an example of how raw data from the Census Bureau can be utilized to overcome some of the shortcomings inherent in Census surveys, as well as some of the limitations in the way data are presented in a user friendly, but "pre-packaged" way on Census gateway interfaces. It needs to be stressed that this analysis did not address some important methodological challenges related to sampling error in the American Community Survey, or reported standard errors or confidence intervals. While we gain flexibility and timeliness by using raw data from rolling surveys, we may lose accuracy because of the complex design factors in the survey.

What we wanted to show was that using the raw data, one can: (1) select a very specific subset of respondents to study, (2) make comparisons that are not possible using only the U.S. Census internet interface, and (3) create new variables to illuminate information that otherwise would remain invisible. We propose such types of analyses as an important component in efforts to inform more flexible and tailored, and less “one-size-fits-all" policies for immigrant communities in the United States of America. 


\section{Endnotes}

1. This research project was conducted in affiliation with the UCLA Center for African Studies and the UCLA National Heritage Language Resource Centers, U.S. Department of Education. The findings and opinions expressed in this report do not reflect the positions or policies of the Department of Education, and you should not assume endorsement by the Federal Government.

2. At the time of writing, the 2006 data had been released and we decided to use the most current data. Observations made about the 2006 dataset apply equally to the 2005 data Pfeifer discusses.

3. Even though Vietnam recognizes 54 ethnic and language minorities, primary schooling would have been in Vietnamese regardless of the linguistic background of a child.

4. The ACS pools grade 5 and grade 6 levels of education attained into one category. This category makes up the $4.1 \%$, which means that some of the respondents in this category strictly speaking may have one year of education beyond what is the primary school level in Vietnam. This particular pooling of the grade levels thus makes it impossible for researchers to distinguish respondents whose highest education level completed was grade 5 from those whose highest education level completed was grade 6.

\section{References}

Hunter, C., \& Harman, D. (1979). Adult illiteracy in the United States. NY: McGraw-Hill.

Kirsch, I., \& Guthrie, J. T. (1977/1978). The concept and measurement of functional illiteracy. Journal of Education, 13(4), 486-507.

LeBlanc, R., \& Painchaud, G. (1986). Self-assessment as a second language placement instrument. TESOL Quarterly, 19, 673-687.

MacDonald, H. (2006). The American Community Survey: Warmer (more current), but fuzzier (less precise) than the decennial Census. Journal of the American Planning Association, 72(4), 491-503.

Macías, R. F. (1988). Latino illiteracy in the United States. Claremont, CA: Tomás Rivera Center. (ERIC Document Reproduction Service No. ED 321 608).

Macías, R. F. (1990). Definitions of literacy: A response. In R. L. Venezky, D. A. Wagner, \& B. S. Ciliberti (Eds.), Toward defining literacy (pp. 17-23). Newark, DE: International Reading Association.

Macías, R. F. (1993). Language and ethnic classification of language minorities: Chicano and Latino students in the 1990s. Hispanic Journal of Behavioral Sciences, 15(2), 230-257.

Macías, R. F. (1994). Inheriting sins while seeking absolution: Language diversity and national statistical data sets. In D. Spener (Ed.), Adult biliteracy in the United States (pp. 15-45). Washington, DC and McHenry, IL: Center for Applied Linguistics and Delta Systems.

Macías, R. F., (2000). The flowering of America: Linguistic diversity in the United States. In S. McKay \& S. Wong (Eds.), New immigrants in the United States: Readings for second language educators. Cambridge, England: Cambridge University Press.

Macías, R. F., \& Spencer, M. (1984). Estimating the number of language minority and limited English proficient persons in the U.S.: A comparative analysis of the studies. Los Alamitos, CA: National Center for Bilingual Research.

McArthur, E. K. (1993). Language characteristics and schooling in the United States, a changing picture: 1979 and 1989. Washington, DC: U.S. Department of Education, Office of Educational Research and Improvement, National Center for Educational Statistics. (NCES Report 93-699). 
Schaffner, J. (2005). Subjective and objective measures of literacy: Implications for current results-oriented development initiatives. International Journal of Educational Development 25, 652-657.

UNESCO Asia and Pacific Regional Bureau for Education. (2007). Secondary education regional information base: country profile - Viet Nam. Bangkok: UNESCO Bangkok.

Venezky, R. L., Kaestle, C., \& Sum, A. (1987). The subtle danger: Reflections on the literacy abilities of America's young adults. (Report No. 16-CAEP-01). Princeton, NJ: Educational Testing Service, Center for the Assessment of Educational Progress.

Venezky, R. L., Wagner, D. A., \& Ciliberti, B. S. (Eds.). (1990). Toward defining literacy. Newark, DE: International Reading Association.

Wiley, T. G. (1988). Literacy, biliteracy, and educational achievement among the Mexicanorigin population in the United States. Unpublished Dissertation, University of Southern California, Los Angeles.

Wiley, T. G. (2005), Literacy and language diversity in the United States. Washington, DC \& McHenry, IL: Center for Applied Linguistics and Delta Systems.

Wiley, T. G., \& Wright, W. (2004). Against the undertow: Language-minority education and politics in the age of accountability. Educational Policy 18(1), 142-168.

\section{About the Authors}

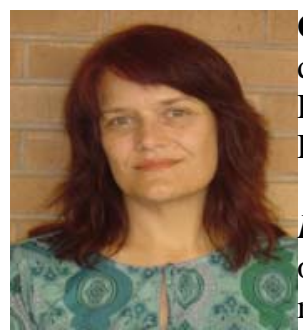

Gerda de Klerk is a doctoral candidate in the Educational Leadership and Policy Studies division of the Mary Lou Fulton College of Education at Arizona State University; and Research Program Director of the ASU-based Immigrant and Refugee Language Community Data Project of the National Heritage Language Resource Center.

Gerda is the author of several scholarly articles and reviews, and is a co-editor of Ebonics in the Urban Education Debate (2 ${ }^{\text {nd }}$ ed.) (2005, Multilingual Matters). She is a native of South Africa, where she was actively involved in the formulation and implementation of multilingual language policies in newly integrated schools. Her academic interests include language policy and language politics, as well as public health policies. She is currently researching elements of the impact of the HIV/AIDS pandemic on education systems in sub-Saharan Africa.

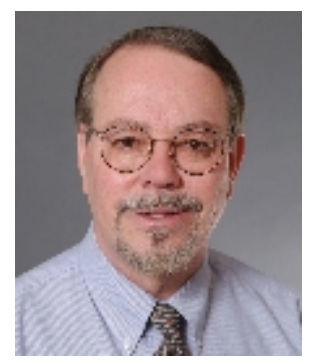

Dr. Terrence G. Wiley is Professor of Educational Policy Studies and Applied Linguistics at Arizona State University, where he is Director of the Division of Educational Leadership \& Policy Studies. His teaching and research have focused on educational applied linguistics, concentrating on language policy, literacy and biliteracy, language and immigration, bilingual education and bilingualism, heritage and community language education, English and globalization, and English as a second and international language. His scholarly articles and reviews have appeared in numerous journals, such as the Modern Language Journal, the TESOL Quarterly, Language in Society, the International Journal of Sociology of Language, Critical Inquiry in Language Studies, the International Journal of Bilingual Education and Bilingualism, and Educational Policy. Among his recent books are: The Education of Language Minority Immigrants in the United States (co-editor, in press, Multilingual Matters), Literacy and Language Diversity in the United States ( $2^{\text {nd }}$ ed.) (2005, Center for Applied Linguistics), and Ebonics in the Urban Education Debate ( $2^{\text {nd }}$ ed.) (co-editor, 2005, Multilingual Matters).

Professor Wiley's editorial service includes co-founding and co-editing the Journal of Language, Identity, and Education and the International Multilingual Research Journal, guest co-editing the International Journal of the Sociology of Language and the Bilingual Research Journal and serving on numerous editorial boards. His current research collaborations include projects with UCLA's National Heritage Language Resource Center and ASU's Confucius Institute in partnership with Sichuan University. His international collaborations and lectures have included work with universities in Asia, Africa, Europe, and Latin America. 


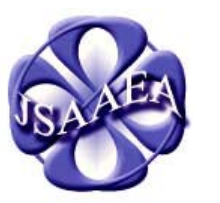

Volume 3

\section{Journal of Southeast Asian American

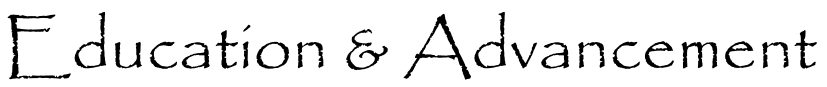

A peer-reviewed scholarly journal published by the National Association for the Education \& Advancement of Cambodian, Laotian, and Vietnamese Americans (NAFEA)

\title{
Editor
}

Dr. Wayne E. Wright

University of Texas, San Antonio

Associate Editors

Dr. Chhany Sak-Humphry

University of Hawaii

Dr. KimOanh Nguyen-Lam

California State University, Long Beach

Book Review Editor

Dr. Leslie Turpin

School for International Training

Creative Works Editor

Phouang Hamilton

Washington Office of Superintendent of Public Instruction

Special Advisor

Anne Frank

University of California, Irvine, Southeast Asian Archives

\author{
Editorial Assistant \\ Mariana Kuhl \\ University of Texas, San Antonio
}

Comments and questions for the editorial staff may be directed to jsaaea@lists.sis.utsa.edu

\section{Editorial Review Board}

\author{
Dr. Carl L. Bankston III \\ Tulane University \\ Dr. Phala Chea \\ Lowell Public Schools \\ Dr. Changming Duan \\ University of Missouri, Kansas City \\ Dr. Nancy H. Hornberger \\ University of Pennsylvania \\ Dr. Peter Nien-Chu Kiang \\ University of Massachusetts, Boston
}

\author{
Dr. Pollie Bith-Melander \\ Asian and Pacific Islander Wellness Center \\ Dr. George Chigas \\ University of Massachusetts, Lowell \\ Dr. Sophal Ear \\ U.S. Naval Postgraduate School \\ Dr. Samlong Inthaly \\ Minneapolis Public Schools \\ Dr. Kevin K. Kumashiro \\ University of Illinois, Chicago
}




\author{
Dr. Stacey Lee \\ University of Wisconsin, Madison \\ Dr. Sue Needham \\ California State University, Dominguez Hills \\ Dr. Max Niedzwiecki \\ Rights Working Group \\ Dr. Clara Park \\ California State University, Northridge \\ Dr. Loan T. Phan \\ University of New Hampshire \\ Dr. Karen Quintiliani \\ California State University, Long Beach \\ Dr. Fay Shin \\ California State University, Long Beach \\ Dr. Yer J. Thao \\ Portland State University \\ Dr. Khatharya Um \\ University of California, Berkeley \\ Dr. Terrence G. Wiley \\ Arizona State University
}

Dr. David Chanpannha Ley

Montgomery County Public Schools

Dr. Bic Ngo

University of Wisconsin-Madison

Dr. Leakhena Nou
California State University, Long Beach
Dr. Mark Pfeifer
Texas A\&M University, Corpus Christi

Dr. Bounlieng Phommasouvanh

Minnesota Department of Education

Dr. Kalyani Rai

University of Wisconsin, Milwaukee

Dr. Nancy J. Smith-Hefner

Boston University

Dr. Myluong Tran

San Diego State University

Dr. Linda Trinh Vo

University of California, Irvine

Dr. Zha Blong Xiong

University of Minnesota

Dr. Kou Yang

California State University, Stanislaus

\section{Doctoral Student Editorial Review Board}

Keo Chea

University of Pennsylvania

Loan Dao

University of California, Berkeley

Ha Lam

Arizona State University

Vanna Som

Harvard University

Giang Pham

University of Minnesota

Tinou Tran

University of Houston, Texas

Phitsamay Sychitkokhong Uy

Harvard University
Vichet Chhuon

University of California, Santa Barbara

Annie BichLoan Duong

San Joaquin County Office of Education

Ravy Lao

University of California, Santa Barbara

Rassamichanh Souryasack

University of California, Santa Barbara

Layheng Ting

State University of New York, Albany

Loan Tran

University of California, Santa Barbara

Yang Sao Xiong

University of California, Los Angeles 